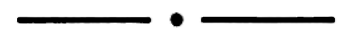

Benedykt Zientara

Acta Poloniae Historica 221970

\title{
NATIONALITY CONFLICTS IN THE GERMAN-SLAVIC BORDERLAND IN THE 13TH-14TH CENTURIES AND THEIR SOCIAL SCOPE
}

1. Following the migrations in the 12th and 13th centuries, important ethnic changes took place in Central Europe. A large number of German colonists mainly peasants and townspeople, who followed, as a rule, the earlier penetration of German knights and clergy, settled in the formerly rather sparsely inhabited areas East of the Elbe, Saale, Böhmerwald, Sumava, and Leitha. A compact German language area moved eastward, surrounding smaller or larger islands of Slavs, while large groups of Germans settled sometimes further to the East.1

This phenomenon, although it has been known for a long time, is still being discussed and commented by scholars. The discussions deal with its causes, effects, and significance to the German people and to the peoples who were the hosts. There are still certain quarters who maintain that the German expansion was

1 No satisfactory synthetic work is available dealing with this process. Existing German and Slavonic papers take at times diametrically opposite positions. The German position is presented in the fullest synthetic outline by R. Kö z s ch ke, W. E be rt, Geschichte der ostdeutschen Kolonisation, Leipzig 1937, and also in articles by $R$. Koebner and H. A u b in in The Cambridge Economic History of Europe, I, Cambridge 1942. Important as regards the methodological bases of this position in $\mathrm{H}$. A u b in's article Zur Erforschung der deutschen Ostbewegung, "Deutsches Archiv für Landes- und Volksforschung," vol. I, 1937. Among the attempts made to revise the traditional viewpoints of German scientists in the post-war period, mention must be made of the article by W. Schlesing e r, Die geschichtliche Stellung der mittelalterlichen deutschen Ostbewegung, "Historische Zeitschrift," vol. CLXXXVIII, 1957 (also in his collected papers Mitteldeutsche Beiträge, Göttingen 1961). The Polish view on the problems of German colonization in the Middle Ages was presented by. Z. K a cz ma rcz y k, Kolonizacja niemiecka na wschód od Odry [German Colonization East of the Odra], Poznan 1945, and M. F riedbe r g, Kultura polska i niemiecka [Polish and German Culture], vol. II, Poznan 1946. Cf. also, collection of papers: Wschodnia ekspansja Niemiec w Europie środkowej [Germany's Eastward Expansion in Central Europe], ed. G. L a b u da, Poznań 1963. An attempt to revise some of the conceptions was undertaken by Polish historians at a conference dealing with PolishGerman relations in the past (1950, especially in the opening report by E. Maleczyniska, 
due to the German nation's spirit of conquest,' or to the nature of the Slavonic soul which is incapable of any creative work unless it is directed by a racially superior (or, in more modern terms - culturally superior) foreign element. It is not difficult to detect in this discussion tendencies that are rather remote from the objective historical truth.

It is difficult to assess the harm caused in this respect by Nazi racial theory. The results are felt even today, for the works written during that period, which often introduced a lot of material and new detailed definitions, cannot be crossed out; but when these works are consulted, it is difficult to prevent people from adopting some not very clear tendencies contained therein. One reader may adopt them inadvertently in their never verified form of "obvious" truths to which he was inured in school, for example. Someone else, brought up in an entirely different spirit, may feel these alleged truths as an incentive to take a diametrically opposite position which may, at times, be equally unjustified. In both cases I am, by the way, thinking of the results of a person unconsciously adopting stock theses without stopping to consider, and I am presuming that the person examining the problem is fully bona fide.

In this way many contemporary German students repeat the theses that urban life was only introduced to the Western Slavs by the German colonization. The idea, formed by legal historians, that a Slavonic commercial and trade centre did become a town only after obtaining the German municipal rights has been so deeply rooted in the minds of German historians, that they are unable to use the term "town" in connection with such centres. In fact, it is easier for them to recognize Timbuctu, Lhassa, medieval Kiev as towns, although they did not possess "municipal rights," than early medieval Prague, Cracow or Szczecin.

The concept of a nation being a community of kin, as a sum total of related tribes composed of related clans (the latter consisting of related families), which still stems from German Romanticism, has markedly handicapped historiography,

whose critical accents have until now lost none of their significance (text in "Sobótka," vol. V, 1950; a German translation was published lately: Polen und Deutschland. W'ssenschaftliche Konferenz polnischer Historiker über die polnisch-deutschen Beziehungen in der Vergangenheit, published by H. L uda t, Köln-Graz 1963). Cf. S. Trawkowski, Zur Erforschung der deutschen Kolonisation auf polnischem Boden im 13. Jahrhundert, "Acta Poloniae Historica," vol. VII, 1962. The Czech point of view was summarised by L. H ra b o vá, K problému némeckè kolonisace ve středni Evrope, "Sborník Historicky" vol. IX, 1962; different views were voised by F. G ra us, Deutsche und slawische Verfassurgsgeschichte?, "Historische Zeitschrift," vol. CLXXXXVII, 1963. The Soviet viewpoint was presented in a volume of articles (written, among others, by authors outside the U.SS.R.) "Drang nach Osten" $i$ istoričeskoje razvitie stran Centralnoj, Vostoćnoj $i$ Jugo-vostočnoj Evropy, Moskva 1967. The most interesting source material concerning the problems of German colonization has been compiled by R. K ̈̈ z sch ke, Quellen zur Geschicht: der ostdeutschen Kolonisation im 12. bis 13. Jahrhundert, 2nd ed. Leipzig-Berlin 1931.

2 The term so often used in journalism and in historical writings to describe German expansion in Central Europe - Drang nach Osten - does not seem scientifically appropriate (at least with reference to those remote times). I shall deal with this matter elsewhere. 
and to an even greater extent the current conceptions. One can still often hear the statement (usually, to be exact, not formed as a clear thesis) that contemporary nations are a direct continuation of the medieval lineage of ethnic communities; a quite recent example was the dispute about the German or Czech nationality of Charles the Great.

Another error still very often encountered in historical writing, and currently spreading in popular science and in school textbooks, is to endow our ancestors with the modern way of thinking, while picturing them without any of the concepts and sentiments which, though they may strike us as strange today, had a paramount place in their mentality. This error is so much more obvious now that contemporary sociology has revealed how completely conceptions and customs change in the process of formation and disintegration of social bonds.

In this connection, he German-Slavonic nationality conflicts which developed in the 13 th to 15 th centuries, are often patterned on 19th century nationality struggles in a Prussian, Russian, or Austro-Hungarian State. The voluminous literature on the subject contains, (apart from works obviously written to order in a wider or narrower meaning of the term, important monographs intended to explain historical processes. It seems, however, that only Marxism, spreading in Central Europe after 1945, has helped to break down the old concepts. Marxism has influenced many historians directly or indirectly, even those who deprecated it; this influence extended indirectly beyond the Central Europe, going through a sort of renaissance in Western Europe, disguised under varied forms. It made possible to take a new look at the nationality problems of the past as well.

2. New presentations of the history of the expansion of the German population in the Middle Ages try to play down its unique character by pointing to analogous migration movements of other West-European peoples, primarily the French. ${ }^{3}$ The outward expression of these processes were the crusades searching

- As a matter of fact, already W. Wa tte $\mathrm{nb}$ a ch (Germanisierung der östlichen Grenzmarken des Deutschen Reiches, "Historische Zeitschrift," vol. IX, 1963, p. 386 ff.) treated the German colonization in Central Europe of the 12th to 14th century as one of the elements of the all-European migration trend; later, however, the peculiar character and uniqueness of the process was being increasingly stressed. (K. Lamprecht, K. Hampe, and others). Lately, views linking the medieval German demographic expansion with the broader migration currents in Europe of that period and with the social and economic changes on a European scale, are widely supported. Cf. F. G ra us, Deutsche und slawische Verfassungsgeschichte?, p. 299 ff.; W. Koro juk, "Drang nach Osten" i istoričeskoje razvitie narodov stran Centralnoj, Vostočnoj i Jugo-vostočnoj Evropy v period feodalizma in the collected work: Drang nach Osten..., pp. 4-7; in comparative studies, however, attention must be paid to the conditions under which the expansion of the various peoples occurred and to the specific nature of such expansion. W. Koro juk (op. cit., p. 7) sees a particularly close analogy between the German medieval expansion and the Polish expansion to the Ukraine, Byelorussia and Lithuania in the 14th-18th centuries; worth stressing, however, is the relatively minor role of planned and compact colonization in the Polish peasant expansion, as a result of which the ethnic areas Byelorussian, Lithuanian, and Ukrainian ethnic areas were curtailed only in a lesser degree. Closer seems an analogy with the Russian expansion, particularly the colonization of Siberia, in which basically all strata 
to find for the surplus population of the West, and particularly for its privileged classes, new places of settlement and expansion in the Levant or in Spain. The victories of William the Conqueror in England were taken advantage of not only by the Norman knights but also by other strata of the local community (especially clergy and townspeople). Many other examples might be quoted.

Similarly, German eastward expansion was also in some measure connected with political conquests. The princes who headed them in the 12th and 13th centuries found that their road had often been paved since the 10th century by the kings and emperors of the Saxon Dynasty. The emperors had succeeded in subordinating the Slavonic territories between the Saale, Bober and Queiss to the German State and to the Church on a secure basis, and to maintain a more or less powerful supremacy over the lands of the North-western Slavs, Czechs and Moravians, and even to assert their claim to sovereignty over Poland and Hungary. In this sense, the Eastern policy carried on by the German kings and emperors of the 10th and 11th centuries may be regarded as preparatory to the expansion of the 12th century, yet the two can by no means be identified with one another. An even greater error is the idea launched by $\mathrm{H}$. Aubin concerning the uniformity of German expansion to the East since the time of Charles the Great up to the colonization undertaken by Frederick the Great and Joseph II.' Combining such divergent and chronologically wide apart phenomena into one event was possible only by taking a mythological view of the nation and its "mission."

In the 12th century, the conquests by the Saxon Princes Adolf II Count of Holstein, Duke Henry the Lion, Albrecht the Bear, The Margrave of the Nordmark, Archbishop of Magdeburg, Konrad Wettin. Margrave of Meissen, led to the domination over another part of Western Slavonia (nowadays Holstein, West. Mecklenburg, Brandenburg, Saxony). These armed conquests were, however, relatively insignificant by comparison with the areas taken over by the German expansion. It should be added that political subordination of a territory did not equal the rate of Germanization.

Longer than elsewhere, partly until today, the Slavs remained in the regions which were under German authority since the middle of the 10th century: Milsko (Milzener Land), Lusatia.

In Slavonic historiography, mainly the Polish, Czech and Russian, various forms of German expansion (imposition of sovereignty upon Slavonic tribes by emperors, conquests by princes building up their dynastic territories, and settlement of the

of the Russian population participated. Cf. the works by V. B a hrušin, collected in "Naučnye Trudy," vol. III (Izbrannyje raboty po istorii Sibiri XVI - XVII vv:), Moskva 1955.

1 H. A ub in, Zur Erforschung..., pp. 47 ff.; lately, also K. Quirin in the introduc. tion to selected source material Die deutsche Ostsiedlung im Mittelalter, Göttingen 1954, p. $7 \mathrm{ff}$; in the selection itself he included the Carolingian Period consistently. Though underlining the differences between the various periods of the history of Slavonic-German relations, G. Labuda (pp. $47 \mathrm{ff}$.) and K. Koro juk (pp. $5 \mathrm{ff}$.) tend in their above quoted articles to regard the German expansion in Central Europe as a uniform process. 
German population in Slavonic countries and in Hungary) were often regarded as various stages and methods of the "life and death" struggle waged between Germans and Slavs. Such a thesis was widely advocated by the Russian Slavophiles, ${ }^{3}$ and found response in Poland ' and Bohemia,' where its traces may be found even today.

No wonder that within that framework one regarded the immigration of German knights, peasants and townspeople into Poland as a "concealed form of aggression" which facilitated the next stage - the political domination of the Slavonic country. According to this conception, the first to appear in the Slavonic country, particularly at the princely court, were German knights and clergymen who gradually gained influence and pushed out the local nobility. Then they facilitated the immigration of townspeople and peasants or colonized the estates obtained from the princes in fief, or else they persuaded the princes and Slavonic magnates to open the door to further German arrivals. The politically poorly experienced Slavonic princes and lords usually fell for such stratagems and the country became inhabited by "enemies." As soon as the latter felt strong enough, they opened the gates to the real aggressors - German princes, margraves, Teutonic Knights - to the considerable prejudice of the Slavonic nations. Only then did the gullible Slavs rub their eyes, get rid of the Germanized and treacherous group in their own ranks which sympathized with the Germans, and endeavoured to fight for national unity and independence.

This presentation cannot be attributed entirely to the reasoning of 19th century historians. It was conceived, in a measure, by Jakub Świnka, Archbishop of Gniezno and most prominent Polish politician of the 13th century, who evolved it as a means of propaganda. In his letter to the cardinals in 1285 , he skilfully

5 J. Pe rwolf, Germanizacija Baltyjskih Slavjan, St. Petersburg 1876, begins his work with the following sentence: "In Central Europe, an important and interesting process has been taking place for the past five hundred years: a fight is being waged by two big Arian tribes - German and Slavonic - a bitter fight which seems to be a matter of life or death to both of these tribes" (p. 1). Similarly A. A. Ko tl ja revskij, Drevnosti Juridičeskogo byta Baltyjskih Slavjan (1874), "Sočinenija," vol. IV, St. Petersburg 1895, pp. 30 ff., and others.

- W. B oguslawski, Dzieje Slowianiszczyzny pólnocno-zachodniej [History of the Northwestern Slavs], vol. III, Poznan 1892, sums up his great synthesis of the Slav-German struggle: "From the German point of view, the conquest of the Slavs behind the Odra River terminates the first act of the great drama of Drang nach Osten which was started in the pre-Christian era and has not yet been completed". Further quotations from Polish historiography were presented by E. Maleczyńska, The Polish-German problem in Polish historiography up to the present, "Sobótka," vol. V, 1950, pp. 7 ff. (cf. German translation quoted in Footnote 1) and G. La bu da, Historiograficzna analiza [Historiographis Analysis], pp. $31 \mathrm{ff}$.

7 Cf., e.g., F. P a la cký, Die Geschichte des Hussitentums und Professor S. Hojler, Prag 1865, p. 75 (cf. K. B it tn e r, Deutsche und Tschechen. Zur Geistesgeschichte des bóhmischen Raumes, vol. I, Brunn 1936, p. 5). "Die böhmische Geschichte ist der Boden, wo von jeher die Gegensätze des Germanismus und Slavismus am starksten aneinander pla. tzen und am klarsten zum Vorschein kommen; ihr Gesamtinhalt ist ein beständiges Ringen des deutschen und slavischen Elementes". 
combined the invasions of Poland by the German princes (in this case he probably referred to the Brandenburgian conquest of Neumark), the settling of German peasants (who refused to pay the tithe more polonico) and the rising of the German Franciscans against the Bishop of Wrockaw, into one single action directed against both Poland and the Church. ${ }^{8}$ The report was intended to arouse the interest of the Holy See in the political and religious relations which prevailed in Poland at the time, and were causing anxiety to the Archbishop in his capacity as defender of ecclesiastic privileges as well as spokesman for the idea of a unified Poland. Jakub świnka's letter is an indication of Polish national consciousness awakened by the Polish-German conflict.

3. The majority of historians agree that the permanent ethnic or, more precisely speaking, linguistic changes in Central Europe were due to colonization by peasants. Leaving aside the clergy, whose immigration did not give rise to new generations of aliens, the knights who had no backing among the representatives of the lower classes of their nationality, were soon absorbed by local nobles with whom they had both class interests and the specific code of chivalry in common, and with whom they were in steady contact. The German burghers, too, whose continuous trade relations permitted them for a long time to draw a steady flow of new blood from the mother country, but who lacked the support of a German rural hinterland, were losing their alien character and assimilating themselves after a certain time. Their upper strata tried to get into the ranks of the local nobility (implying adoption of language and customs); the lower strata, strengthened by the influx of peasants from Slavonic villages surrounding the towns, had to conform with them linguistically. Even in a region like Livonia which maintained uninterrupted contact with German towns, and where the town population kept their German language and their sense of being different for centuries, this fact had no bearing on the overall picture of the country. Only the many peasant communes located in larger territories, separated by law from the local population and therefore not compelled to maintain steady contact with them in their local language, could serve as foundation for the creation of a compact foreign language area. We learn from sociological studies on the settlement in modern times about the compactness of such communities, their conservatism, their faithfulness to the mother tongue and traditions, and also of their enormous fertility which caused an unusually high birth rate (doubling of the population within a period of 23-26 years).' These factors explain to some extent the riddle of how a relatively small number of colonists could populate such vast areas. One should also consider the fact that colonists were a sort of selected type of people with a special turn of mind which manifested itself, among others, in extraordinary mobility: sons of colonists, with the exception of the immediate heir to the estate often even the colonists themselves wandered off, as a rule, discouraged by condi-

8 Codex diplomaticus Maioris Poloniae, vol. I, Poznaniae 1877, No. 616, pp. 574 ff.; reprint in $\mathrm{R}$. Kotzs chke, Quellen...

- W. K u h n, Die Siedlerzahlen der Deutschen Ostsiedlung in: "Studium Sociale" (Mélanges K. V. Müller), Köln-Opladen 1963, pp. $132-136$. 
tions, leaving the settlement they had built, to look for better luck somewhere else. ${ }^{10}$

What did the peasants and townspeople look for in the East? We do not find it mentioned in any source material that they yearned to conquer new territories for the "fatherland" or for the German "language." There was no common German "fatherland" at that time, nor was there any common "German language"; the Slavs called the language of the newcomers "German language" they had discovered the German community earlier than the Germans themselves. It was no accident that the German literary language (Neuhochdeutsch) came into being in the Slavonic lands (Bohemia, Meissen) in the 14th century - out of the joint dialects of the colonists from the South and Central Germany. The colonists looked for no political aims but for a better and more free way of living, as described in a song sung by the Flemings, the pioneers of the entire movement who had founded it in the 12th century."1

But if they did not think of themselves as "secret aggressors", they acted perhaps as unconscious tools of aggression?

We know, of course, of cases where German colonization had to play an eminently political role as a factor which strengthened the rule of the German dukes in the lands they had conquered. This is what happened during the period of the conquest of Wagria by Count Adolf of Holstein, when the Hollenders, the Zelanders, the Friezes, etc. (not counted as Germans nowadays), whom he had summoned, were to defend the newly conquered territories against any Slavs trying to reconquer them; this caused the resettlement of Slavonic peasants in a compact area and their separation from their kinfolk by newly colonized centres. ${ }^{12}$ In this instance the relationship of the newcomers and the local population was, obviously, not friendly, but the basis for the antagonism was, after all, religion. The same was the case in Brandenburg, where fortified "towns" (with a rural population) were built along important strategic roads; such centres and roads constituted the skeleton of the new state, which was then gradually filled in accordance with a planned colonizing campaign." Of a political and military character as well was the settlement

10 An interesting attempt at applying the results of sociological research among emigrants to historical migrations was made by J. U. Folke rs, Die Geschichtliche Bedeutung der Landnahme als Auslesevorgang, "Deutsches Archiv für Landes- und Volksforschung," vol. V, 1941, pp. $506-569$. The value of the work is impaired by its strong racist tendencies.

11 "Naer Oostland willen wij rijden - Deer isser en betere stee".

12 Helmoldi presbyteri Bezoviensis Chronica Slavorum ed. B. S ch me idle r (1937), quot. from "Ausgewählte Quellen zur deutschen Geschichte des Mittelalters," vol. XIX. Darmstadt-Berlin 1963, I c. 57; J. U. Folkers, Zur Frage nach Ausdehnung und Verbleib der slavischen Bevélkerung von Holstein und Lauenburg, "Zeitschrift der Gesellschaft fur schleswig-holsteinische Geschichte," vol. LVIII, 1929, pp. $339-448$.

1" W. G I y, Die Besiedlung der Mittelmark von der slavischen Einwanderung bis 1624, Stuttgart 1926, p. 104 ff.; lately W. H o p p e, Biesenthal. Zur askanichen Besitzergreifung des Barnim, "Jahrbuch für brandenburgische Landesgeschichte," vol. II, 1951, pp. $26-29$, reprint of the sa m e: Die Mark Brandenburg, Wettin und Magdeburg, Ausgewählte Aufsàıze, Köln-Gratz 1965. 
movement of the Teutonic Order in the first stage of their conquest of Prussia along the Vistula Bay.14

Yet, wherever colonists were brought in by Slavonic kings, princes or nobles. we can hardly impute to them the intention of undermining the independence of their own country or even "high treason." The main and usually the only aim of the rulers - whom the magnates imitated — was, as Polish historiography stresses lately - melioratio terrae, or improving the country by increasing the density of population, the improvement of agriculture, the establishment of masters - subject relations on new bases, the revitalizing of town life, trade, etc. To the ruler the welfare of the country was identical with his own welfare, as in the past: now, however, the increase of his own income was not at variance with the interests of his new subjects - colonists privileged in comparison to the local population. The prince gained their gratefulness and support and could rely on them in any conflicts with a secular or ecclesiastical noble opposition.

Any favouritism arouses ill-feeling, especially when aliens get privileges over the local population. Ill-will was fanned by the foreign language of the newcomers, their customs, games, songs. And yet - in spite of the extent of German colonization of the countryside in the vast areas between Elbe, Memel, Saale, Böhmerwald and Transylvanie, one very rarely heard of any bloody conflicts between peasants of different nationalities. Only one such case happened during the first stage of colonization, when Slavs were resettled on poorer soil and their country seats allotted to colonists in the region between Elbe and Odra. The expelled people harrassed the new occupants of their former possessions repeatedly, hoping to take their heirloom back, and their resistance against the unjust decisions often took the form of a return to paganism. At a later stage of an already well-developed colonization the Slavonic peasants, Christians by then, took a different line they demanded equal rights with the colonists, i.e., to be granted the so-called German Law. The rulers were not always favourably disposed to agree; it was not easy for them to give up the special dues and duties demanded of this category of peasants. I believe that the placing of Slavonic peasants under the German Law was due not only to the conscious action of princes and nobles within the framework of melioratio terrae but also to pressure exerted by the peasants themselves who demanded rights similar to those of their German neighbours.

The national consciousness which developed most strongly among the Slavonic peoples in the Middle Ages was that of the Czechs; it also penetrated more deeply and dominated to a greater or lesser degree nearly all strata of society. ${ }^{15}$ The development of this consciousness was, since the early 14th century, closely related to the dislike of the German element; it was increasing in Bohemia during the century and found its culminating point in the Hussite Rising. There were

14 B. Schumacher, Geschichte Ost- und Westpreussens, 3rd ed., Würzburg 1958, pp. $34 \mathrm{ff}$.

15 The development of the national consciousness of the Czechs was lately accurately presented by F. Graus, Die Bildung eines Nationalbewusstseins im mittelalterlichen Böhmen (Die vorhussitische Zeit) "Historica," vol. XIII, 1966. pp. 5-49. 
other Slavonic peoples living then in Bohemia besides the Czechs, primarily Poles in Silesia and Serbians in Lusatia. Characteristic here is the fact that this trend was limited to the Czech people who possessed a stratum of educated clergy and a strong class of knights whose cultural level was also high. In Slavonic Lusatia there was no sign of Czech influence in the anti-German rural movement. In Silesia, too, such influence was rather insignificant.

The reason lay in the social content of the national ideology of that period, which addressed itself almost exclusively to the privileged strata: the knights, the clergy, and the townspeople. It got no response from the peasants, and nowhere - Bohemia excepted - can any trace be found of peasants ever rallying to its banners. Thus the Slavonic peoples who did not have their own ruling class remained indifferent to the anti-German appeals of the Hussites, thus missing the chances of awakening their national consciousness. The peasant, exploited and disliked by practically all other social strata - the clergy as well as the nobility and the burghers, up to and including the travelling pedlars who cheated him - remained aloof and maintained his reserve in the face of the quarrels carried on among members of the privileged classes. This does not mean that he remained passive: when the quarrels affected him too badly, he would grab his scythe and flail to beat back the invader, the destroyer, the oppressor be it the German crusader in Bohemia, the Hussite in Silesia and Pomerania, or the Teutonic Knight in Kuyavia.

Nor were towns at first a spot of national conflicts. In planted towns authority was transferred to the Germans, the only ones conversant with the new municipal rights. The town community was a privileged unit of society; Slavs admitted to it realized the advantage of the very fact of belonging to it. At first it was easier for them to obtain the privilege at Lubeck or Wismar " than in Cracow, where the privilege of the prince prohibited Poles to be accepted under the municipal rights: ${ }^{17}$ neither because the colonizers (locatores) intended to maintain ethnic "purity" of the alien community on Polish ground, nor because the prince wished to keep the subjects of the two nationalities apart, but because the prince, as well as the Church and the nobles feared a massive run of peasants to get under the authority of the free town community, where "the air alone makes one free." In Cracow, the principle that Stadtluft macht frei did not become binding fortunately this point was not observed.

Nationality conflicts in the towns started later with the town system growing less flexible. The group of families ruling in a town, going under the scientific name of patricians, jealously guarded its power against the masters of the guilds who demanded a share for themselves. The guilds limited their membership, fixed

1" J. B i / e k, Die Herkunft der slavischen Minderheiten in den mittelalterlichen Städten Mecklenburgs. "Bodendenkmalpflege in Meklenburg," Jg. 1959, pp. 229-236.

1i Codex diplomaticus Civitatis Cracoviensis, ed. F. P i e k os iński, vol. I, Kraków 1879, No. 1, pp. 1 ff.: "Hoc eciam nobis idem advocati promiserunt, quod nullum ascripticium nostrum vel ecclesie, seu cuiscumque alterum, vel eciam Polonum liberum, qui in rure hactenus habitavit, faciant suum concivem". 
output of workshops and the number of journeymen and apprentices therein employed. Every new master, every new workshop involved a reduction of profits for the others, and therefore every effort was made to render the opening of workshops by new people as difficult as possible. Among them were many peasants trying to find better living conditions in town - in the areas under consideration they were predominantly Slavs. The peasant as such was already sneered at by the townspeople who treated him like something nature itself had made to be exploited. A peasant's pursuit to advance was dangerous and met with hostility, so much more so when he was a Slav peasant with strange customs and language. This motivated the prohibition of admitting Slavs into the guilds from the middle of the 14th century on, and later the prohibition of granting them citizen's rights. Starting from Meklenburg and Brandenburg, the wave of prohibitions spread to other areas, also to those where the authority was not in the Germans' hands. ${ }^{18}$ This wave collided with another one: Slavonic elements coming to the towns demanded a greater share of the privileges, in the town's authorities, in the profits from the town's income. The outcome of the struggle for municipal rights depended upon how the forces were distributed. Wherever German elements had the upper hand, the Slavs had to accept the prohibition and use back doors to get wherever they were prevented to pass through the main entrance. To succeed in such cases, they had to assimilate the culture, the customs, and later the language that held sway among the ruling circles. Wherever the Germans in a Slav environment had no prospects of maintaining the monopoly of power and had to get themselves assimilated, they quickly capitulated. Wherever both sides were equal in force, as, for example, in the Bohemian towns, there were sharp nationality conflicts which contributed to fierce nationality struggles on a countrywide scale.

4. Although the influx of foreign townspeople, and especially of peasants determined, if their numbers were sufficient, the future of the language pattern within the territories they occupied, it did not have a decisive influence so far as the arising of nationality conflicts were concerned. Decisive in this respect were the strata which created the specific culture that tinged the whole of the feudal period - the clergy and the knights. By the same token that the influx of Mazurian peasants did not change the German character of the State of the Teutonic Knights, and the colonization of the Carpathian Mountains by the Walachians did not lead to the creation of nationality conflicts in that region, the bringing in of foreign peasants and settling them with their own rights in the regions they cleared did not create any antagonism between Germans and Slavs. Antagonism arose not on the fields and not in peasants' huts but in castles and monasteries.

18 D. G. H o p p, Die Zunft und die Nichtdeutschen im Osten, insbesondere in der Mark Brandenburg, Marburg/Lahn 1954, pp. 61 ff.; W. Z o n, Deutsche und Undeutsche in der städtischen Rechtsordnung des Mittelalters in Ost-Mitteleuropa, "Zeitschrift für Ostforschung, vol I, 1952, pp. $182-194$. 
The first German knights and priests seem to have come to the court of Poland earlier than the name of Poland in the sources. Stress as we may the Roman influence upon the Polish Church in the 10th - 12th centuries, the activities of the French and the Italians take second place after those of the German clergy. Next to the Czechs, the Germans were the natural, closest intermediaries between Poland and the cultural centres of the West France and Italy. Of course, whatever they transmitted, was not "German culture" but a purely Latin treasure of civilization inherited from ancient Rome and enriched by later achievements of all Latin peoples. But the outer form in which this civilization was brought to Bohemia and to Poland, was German. Neither the works of the French trouvères nor those of the troubadours from the Provence became popular, but the local knights admired imitations written by German lyrical poets. While French culture and language became popular in German castles and manors, the German language became popular among the ruling classes in Poland and Bohemia, on Isle of Rugen and in Pomerania. Emperor Frederick II wrote poems in Provençal, Venceslas kings of Bohemia and price Henryk Probus of Wroclaw - in hochdeutsch. Witzlaw III, Prince of Rugen also wrote poems in this latter language, though it was not the language of his subjects, not even of his German subjects, who spoke niederdeutsch.

So long as individual German clergymen and knights were arriving at the Slav princely courts, they got assimilated fast, just as did the German spouses of these princes. The monasteries kept their national differences for longer periods, especially the Cistercian monasteries, whose filiation system facilitated the recruiting of new blood from abroad. The problem changed when in the 13th century, immigrants arrived in larger numbers mostly as ministeriales who were looking for social advancement in the Slavonic countries and were gladly received because of their military skills and their familiarity with the achievements of chivalric culture. While popularizing this new culture, the Germans obtained desirable positions at the princely courts and remunerative ecclesiastical benefices. German knights, who usually arrived in Slavonic countries empty-handed and owed everything they got to the local rulers, often supported the latter in their struggle against the powerful Slavonic nobles who opposed them. Among others the sudden disappearance of the majority of Slavs from the list of witnesses in documents of the Pomeranian princes after 1230, may be ascribed to internal conflicts in which the princes relied on the support of homines novi of foreign stock. Similarly, Prince Henry IV of Wroclaw relied upon clergymen of German origin in his fight against Bishop Thomas II and the Polish clergy who were loyal to him. Waxing in importance and proud of being so popular with the rulers and of their successful career, the Germans often, perhaps even most of the time, assumed that irritating attitude of superiority of which we learn from the poems written by a monk from monastery of Lubiąż (Leubus) in the 14th century. ${ }^{10}$

10 Monumenta Poloniae historica, vol. III, Lwów 1878, pp. 708 ff.: "Nam sine cultore tellus iacuit memorosa Et gens Poloniae pauper fuit haut operosa, Sulcans in sabulo lignis 
This was, indeed, the origin of the Slavonic-German antagonism. The first and most serious reproach made by the Polish and Czech clergy and knights against the Germans was that they were greedy and forcing local people out of their positions and property. The fact of being barred from any career at the Court or in Church made the local people react in two different ways: some endeavoured to ressemble the Germans as much as possible, to adopt their language, or at least their customs, and thus to neutralize their so-called advantages; others withdrew from the competition and formed an opposition ready to remove the new favourites by force. In this opposition knights and clergy often found a common language. The dislike for German knight and for German clergyman easily spread to include the German burghers, another cause of this being their different social class. Rich plebeians preening themselves with their culture and making money by exploting the local population, including the opposition, presented an excellent target for hatred. All three groups spoke the same language and had foreign customs in common - this synthesis formed the image of the German - of the enemy aiming to exterminate the Slavonic nations, known already from source material dating back to the 14th century - from the chronicles of the so-called Dalimil ${ }^{20}$ and from songs about the advocatus Albert. ${ }^{21}$

5. The assumption that the medieval concepts of national consciousness were identical with those valid in modern times far better known to us, has given rise to misunderstandings in historiography, the harmful effects of which are still rampant today.

It is important to stress that medieval nationality feuds arose primarily in areas where two nations were in touch, within the frontiers of one state, and where there was rivalry between two equally strong elements. ${ }^{22}$ At its origin lay the feeling of hostility towards the alien which has been common to all peoples since the beginning of history; a feeling which also made for stronger bonds with those

unus uncis sine ferro Et vaccisve bobus nisi scivit arare duobus. - Non sal, non ferrum, nummismata nonque metallum, non indumenta bona, sed neque calciamenta Plebs habuit illa, pascebat sola iumenta. Delicias teles monachi reperere rpiores. Est takem hec terra per eos hiis tota referta. Abduxere, quis per quos sunt cuncta reperta" -

20 After 1310 there appeared the Bohemian rhymed chronicle at first traditionally linked to the name of Dalimil, nowadays ascribed to Henryk Žak of Dubé, a later Bishop of Olomouc (Olmuitz) published in Fontes rerum Bohemicarum, vol. III, Prague 1882. On the Greed of the Germans, p. 131; on their endeavour to destroy the Checks p. 122: "Všichni Némci českeho zlého hledaju."

21 A composition in rhyme conceming Albert, the advocatus of Cracow and leader of the abortive rising of the German townspeople against Ladislaus Lokietek, published by E. D lug opolski, Bunt wójta Alberta [Advocatus Albert's Revolt], "Rocznik Krakowski," vol. VII 7, 1905, pp. 184-186. On German greed cf. p. 186: "Ad hoc traxit me matura, Que est Almanorum cura, $U t$, quocunque veniunt, Semper volunt primi esse Et nulii prorsus subesse, Ad hoc se sic muniunt"; on the endeavour to destroy the Czechs, ibidem: "Sic Bohemi sunt delusi, De bonis suis detrusi Ab ipsis Theutunicis, Et jam quasi perierunt..."

22 Cf. M. Ha ndels ma n, Le Rôle de la nationalité dans l'histoire du Moyen Age. "Bulletin of the International Committee of Historical Sciences," vol. VII. 1929, pp. 235 - 247. 
of "our own kind". ${ }^{25}$ Initially it was hostility against a foreign language one did not understand (this accounted for the Slavs' defining foreigners by the term Niemcy, i.e., "niemi" - dumb, not knowing the language, this definition narrowed down to Germans only later); it must, however, be added here that minor linguistic differences were dealt with similarly, because it was considered that "the stranger" using a related dialect "distorted" and murdered "the genuine" language (quarrels between Saxons and Bavarians, Poles and Czechs). Add to the differences in language the differences in clothes; in a situation of mutual dislike even a relatively insignificant trifle could bring on an armed clash, and bloodshed led to hostility and turned into hatred. Thus, although Poles and Czechs were conscious of the close resemblance of their languages throughout the Middle Ages, their antagonism towards each other in the 12th century was not less acute than their hatred of the Germans. ${ }^{24}$ With the obliteration of ethnic frontiers, when people of various origins intermingled, two roads became apparent. One was the road to a natural drawing due to living together under the same conditions, getting to know each other better and exchanging cultural values; this was fostered by a common religion, usually common ideas, and the fact of being the subjects of the same state and loyal to the same ruler. The other road led to greater differences and hatred between both nationalities; contributing to this state of affairs were the legal differences favouring the newcomers, kept up by some rulers and princes of the Church. Particularly menacing situations arose when the national divisions were roughly equal to the class one. The conflict then spread to larger strata of society, class struggle often turned to national struggle, and the exploiter who spoke a foreign language was hated for yet another reason. The development of a population of mixed nationality advanced simultaneously along both roads. The ascendancy of one over the other depended on other more general conditions, mainly social and economic conditions coupled with intensified class struggle - factors which determine the social scope of a conflict. In the early stages nationality conflicts did not, however, play a decisive role in the lives of society - they were limited territorially, and national ties which did not include the basic masses of the population, namely, the peasants, could hardly call the tune in social life and culture. ${ }^{25} \mathrm{~A}$ characteristic feature of the

25 Cf. the accurate remarks by R. W e n s k u s, Stammesbildung und Verfassung, KölnGraz 1961, pp. 14-107, on the shaping of the consciousness of tribal communities.

$24 \mathrm{Cf}$., e.g., the opinion of Gallus Anonimus, Polish chronicler at the beginning of the 12th century: "- cum Bohemicis, Polonorum infestissimis inimicis" (Galli Anonymi Chronicae et gesta ducum sive principum Polonorum, ed. K. M a e c z ý sk i, Monumenta Poloniae historica, Nova Series, vol. II, Kraków 1952, vol. I, 18, p. 41); cf. also vol. II, 20, p. 145, vol. III, 23, pp. 23 ff. As for Kosmas, Bohemian chronicler contemporary of Gallus, vide B. K rzemińska, Polska $i$ Polacy $w$ opinii czeskiego kronikarza Kosmasa [Poland and the Poles According to the Opinion of Bohemian Chronicler Kosmas], "Zeszyty Naukowe Uniwersytetu Lódzkiego," I series, 15th issue, 1960, pp. 75 - 95.

25 An outline of all problems pertaining to the development of national consciousness in the German-Slavonic borderland during the period of nationality conflicts has been shown (but in an apologetic spirit, from the German angle) by E. M a schke, Das Erwachen des Nationalbewusstseins im deutsch-slavischen Grenzraum, Leipzig 1933; a more balanced 
national consciousness in a feudal society are its limitations which are both social and territorial; the farther away from the crucial point of friction with foreigners, the lesser was the national consciousness (Mazovia in Poland). Other allegiances were, as a rule, more important - allegiance to the State in the rising centralized monarchies assumed ever greater importance, creating (above the particular interests of individual social groups) a common entity benefiting all inhabitants of the State, symbolized by either a monarch (France) or a more abstract concept, like Corona Regni or Res Publica (Central Europe). Older and more important were the religious (and cultural) bonds uniting all Christians in sentiment and hope, habit and custom. The firm conviction of the impermanence of our world made people care more for their eternal life; between local and regional ties and the overall bond of Christianity, little room was left for any national community. Thus the frictions in the German-Slavonic borderland were not conducive to the creation of a national sentiment, either among all Germans or among Poles or Hungarians. Only where national interests coincided with religious interests (Bohemia) did national antagonism grow more intense and sway the masses only in this light one can understand the overtones of an almost modern nationalism in the Hussite Movement and the fact that virtually the whole Bohemian nation participated in the movement. The national feeling of solidarity of the Czechs in the 15th century spread temporarily among all strata of the population because of its indissoluble bond with religious convictions. ${ }^{20}$

judgment was presented (for Bohemian) by $\mathrm{K}$. B i $11 \mathrm{ner}$ in a richly documented work: Deutsche und Tschechen...; a specially valuable contribution to the discussion on nationality problems of Bohemia in the Middle Ages is F. Graus' article quoted in Footnote 15. For the Hussite period (besides Bittner) vide J. M a č e k, Národnostni otázka v husitském revolučnim hnuti, "Československý Ćasopis Historický," vol. III, 1955, pp. 4-30. The Polish side of the problems was dealt with by: O. B a $1 \mathrm{ze}$, Polonia, Poloni, gens Polonica w świetle źródel drugiej polowy XIII wieku [Polonia, Poloni, gens Polonica in the Light of Source Material of the Second Half of the 13th Century], in: Ksiega pamiqtkowa B. Orzechowicza, vol. I, Lwów 1916, pp. 71; Królestwo Polskie [Kingdom of Poland], vol. I, Lwów 1919, pp. 41 -171; K. T y m i e n i e k i, Poczqtki narodowości polskiej [Origins of Polish Nationality], "Przegląd Współczesny," vol. XVII, 1939, No. 7(195), pp. 3-29; R. G ro d e c k i, Powstanie polskiej świadomości narodowej [Origins of Polish National Consciousness], Katowice 1946; J. B a szkiewicz, Powstanie zjednoczonego państwa polskiego na przelomie XIII i XIV wieku [The Rise of a United Polish State at the Turn of the 13th and 14th Centuries], Warszawa 1954, p. 435 ff. For comparison, see the interesting study on national consciousness at the western frontier of the Empire. Cf. J. $\mathrm{H}$ u iz in $\mathrm{g}$ a, Aus der Vorgeschichte des niederländischen Nationalbewusstseins in: Wege der Kulturgeschichte, München 1930, pp. 208 ff.; E. Lemberg, Wege und Wandlungen des Nationalbewusstseins, Münster 1934; W. Re es e, Die Niederlande und das deutsche Reich, Berlin 1941.

26 Cf. the words of the Hussite hymn Ktoż jsú boží bojovníci: "Na to jim řekli Cechové, że neustoupi viry své a vlasti své chtí hajiti" (Whereupon the Czechs replied, that they would not forsake their faith and would defend their fatherland). The link between the defence of faith and fatherland emerged very forcefully in Poland at a later period during the wars waged against non-Catholic enemies (Turkey, Moscow, Sweden). This Messianism of feudal societies must, however, be clearly distinguished from the "idea of a nation's mission", which appeared in the nationalisms of the 19th century and often assumed a religious character (e.g. Polish Messianism). 
Another normal phenomenon is a much faster and more buoyant development of national consciousness among national communities facing danger and those who are expanding. Passionate declarations like the statement of Jakub Świnka, Annals of Great Poland, Annals of the Cracow Chapter, the Dalimil chronicle and the song about the advocatus Albert are countered by cool replies contained in German sources of the 13th and 14th centuries, which is either tinged with disdain for the Slav population and its cultural level, or else confined to the mere statement of fact that Slavs and Germans hate each other for incomprehensible reasons. When a Czech chronicler at the beginning of the 14th century appealed to his countrymen to unite and defend the Czech language against their common foe, when, in the Hussite Period, there emerged even the idea of a Slavonic community resisting the Germans, we see no analogy on the opposite side.

On the contrary, the first generations of immigrants took root in the local soil so vigorously that they even looked upon their countrymen arriving some scores of years later as foreign intruders. Union with the idea of the Holy Empire did not equal patriotism. The 14th century saw the development of West-Pomeranian patriotism above all in the old-time German settlers in Western Pomerania, who fervently defended the land and the dynasty against the designs of the Brandenburgians. ${ }^{27}$ It also saw as extraordinary an event as the translation into German, in Bohemia, of the anti-German chronicle of Dalimil, a translation made by and for the use of the older strata of German settlers who disliked the new fortuneseekers from the West as much as did the Czechs. In this translation, very characteristically, the word "German" was replaced by the word "alien". ${ }^{28}$ Some score of years earlier, the German poet Ulrich von Eschenbach praised the "happy land" (saelege land) - Bohemia, and traced the etymology of its name (Boheim) he had "engraved in his heart", to beatus heim. Czechs and Germans were falling on the battlefields at Dürnkrut, in Lombardy, in Prussia and at Grécy for the greater glory of Bohemia and its king; and promoters of the ideology of the Hussite Movement were the German preachers Konrad von Waldhausen and Nicholas of Dresden as well as German Waldenser peasants from the border region of Lower Austria and Bohemia. ${ }^{20}$

Many examples of loyalty sometimes almost of patriotism of German immigrants to their new homeland, could be quoted with reference to Poland as well. Henryk Kietlicz, sr., defended Mieszko III against the revolt of the nobles; Peregrin von Wiesenburg shielded prince Henry the Bearded with his own body from the blows of the assailants. Many German knights, miners and peasants fell side by side with Poland's knights in the battle of Legnica (1241) fighting the

$22 \mathrm{~J}$. P e ters oh n, Reichspolitik und pommersche Eigenstaatlichkeit in der Bamberger Stiftung Herzog Barnims III zu Ehren des hl. Otto (1339), "Baltische Studien", Neue Folge, vol. XLIX, 1962/63, pp. 19 - 38.

${ }_{28}$ The chronicle published together with the Czech original Dalimil in Fontes rerum Bohemicarum, vol. IIl (cf. footnote 22), E. M a s ch ke, Das Erwachen..., p. 45; F. G ra u s, Die Bildung..., p. 33.

29 K. B i $t 1$ n e r, op. cit., p. 55. 
Mongols. When settling in Poland, the newcomers also allied themselves with local families; armourists and genealogists find it really difficult today to define who of the knightly families were of local stock and who of foreign stock. There happened to be families as complex as that of the Constable of Silesia Albert the Bearded called Lyka, whose father was a German, mother a Walloon, first wife a Pole, and second wife again a German. ${ }^{30}$ The well-known Silesian scholar Vitelo found it difficult to define his nationality; he therefore referred to himself as "filius Thuringorum et Polonorum"." On the other hand, Martin of Troppau Archbishop nominee of Gniezno and author of a renowned chronicle, was called Polonus, though he was, in reality, a German from the Kingdom of Bohemia. ${ }^{22}$ Later numerous townspeople of undoubtedly German stock, living in Polish towns, called themselves Poles. Prior to the bloody reprisals in Cracow against people who were unable to pronounce Polish words like soczewica, koto, miele, mlyn," the German Cistercians passed their evenings in Henryków listening to the anecdotes of the retired fool of the prince, Kwiecik, nicknamed Kika, and after his death they never forgot to pray for his soul.".

The first "German villains" known in Poland were the Raubritters called in by duke Boleslaw Rogatka of Silesia, and the Franciscans (late 13th century). The former contributed to turning the prince's political battles into highway robbery, the latter tried to take advantage of the prince's feud with the bishop to improve their positions at the time when rivalry was rampant within the Silesian Church. Secret rivalry then changed into open warfare, but it was by no means a "rising" of the German element against the Polish State, as some authors would have it.

The feeling of being menaced which spread among ever broader masses of the Polish clergy and knights contributed to making the struggle for the country's unification more popular. This struggle was associated in the minds of the people with the struggle against the alien intruders, particularly after the rule of the Przemislides in Poland and with the new masses of foreigners who had arrived while they were in power.

The majority of German townspeople in Poland declared their agreement to the country under one scepter (of the Przemislides and their successors, the Lux-

:0 Liber fundationis claustri Sancte Marie Virginis in Heinrichow (Cistercian chronicle, Part I of which was written in the second half of the 13th century), pub. R. G rodecki, Ksiega Henrykowska, Poznań-Wrocław, 1949, vol. I, c. 3, pp. 256-60.

st A. B irke nma jer, Witelo, najdawniejszy ślqski uczony [Witelo, Most Ancient of Silesian Scholars], Katowice, 1936, p. $11 \mathrm{ff}$.

"1 J. Kloczowski, Dominikanie polscy na slqsku w XIII-XIV wieku [Polish Dominicans in Silesia in the 13th-14th Centuries], Lublin 1956, p. 231.

s: Information of this kind of reprisals taken against German townspeople who revolted against the prince was, however, reported only by one source, Annals of Krasinski, compiled in the 16th century on the basis of unknown sources Monumenta Poloniae Historica, vol. III, p. 133. In view of the fact that the date given in the Yearbook, besides many other data, is incorrect, the whole - quite indicative relation - should be placed among the legends.

s4 Liber fundationis.... vol. I, c. 8, pp. 277 ff. 
emburgs); it must be remembered that this conception held the promise of advantages for townspeople - the combining in one state the three main Central European trading centres - Prague, Wroclaw and Cracow.ss Extending the state of Venceslas II to the Baltic Sea would have been of considerable importance to the Bohemians as well. One can, of course, hardly speculate about what might have happened had the Luxemburgs obtained the Polish Crown. But knowing of the intention of Charles IV to open a commercial lane to the Baltic Sea to the Bohemians one may assume that, as King of Poland, he would not have been too welcome a neighbour for the Teutonic Knights, Poland's enemies, with whom he had a standing alliance.

The Bohemian idea of uniting Poland - which even Jakub świnka advocated for a time - could not have been popular with Polish society, or rather with the Polish nobility and clergy - for there was now, in addition to Germans already at the princely courts, a powerful mass of intruders - Germans and Czechs grabbing for themselves the most important positions. That was ground enough for the general feeling of the Polish population to turn to steadfast Wladyslaw Lokietek who became the national candidate from then on. Only the local Germans, who had warmly supported the Przemislides related to them in their culture, did not discard the "Bohemian conception" fast enough. Soon after John of Luxemburg had assumed power in Bohemia and asserted his claim for the Polish Crown, his partisans staged an open revolt in Little Poland against Prince Wladyslaw Lokietek (1311-1312). In that revolt participated the monks of the Holy Sepulchre from Miechów, the towns of Wieliczka and Sandomierz and, probably, Bishop Jan Muskata; of the greatest importance, however, was the rising of the bourgeois in Kokietek's capital Cracow, headed by the advocatus Albert (after whom the historians called it the Albert Rising). The partisans of the Luxemburgs took over the city and installed there as Jan's governor Boleslaw, Prince of Oppeln; they did not, however, succeed in conquering the castle of Wawel. The overwhelming majority of Luxemburg supporters were Germans, which made the fight against them look like an anti-German campaign. It ended fast with the defeat of the insurgents and with reprisals against those who had participated, especially the townspeople. They had to pay dearly for it. But not all Germans from Little Poland had taken part in the revolt - Nowy Sącz, for example, had not backed Cracow but stood firm by Lokietek, although its patricians did not differ greatly from those in Cracow so far as the composition of nationalities was concerned. The balance was tipped by interests and economic rivalry.

The suppression of the Cracow revolt took the form of reprisals against the German element; among others, German was barred as official language in the administration. But there the matter ended. From then on the Cracow townsfolk loyally supported the Piasts - especially Casimir the Great - and their influence

35 J. Śusta, Václav 1 a a koruna polska, "Český časopis historický", vol. XX, 1915, pp. $313-346$, cf. ibidem, Dve knihy českych déjin, vol. I; cf. also for a negative appraisal of the Vaclav expansion in J. B a szkiewicz, Powstanie zjednoczonego państwa [Rise of a United State], pp. 203 ff. (who agrees on this point with O. Balzer). 
in strengthening the power of the State must not be underestimated. State patriotism superceded the differences among nationalities which were relegated to become municipal affairs. And this was not only the case in Cracow. The list of witnesses - Polish townspeople of German origin, who testified before the Papal Court against the Teutonic Knights in favour of Poland, was considerable.

6. The national consciousness of Poles and Czechs developed along the following lines: they went from the instinctive dislike of an individual who spoke a foreign language and brought with him strange customs, to hostility towards the alien intruder who occupied positions and grabbed incomes that were due to the indigenous population, and thence to the realization of the fact that people speaking the same language had common interests and had to defend themselves against the influx of alien people and a foreign language. The former concept of patriotism which had been linked to the dynasty and the homeland and conceived, in various ways, mostly narrowly, became stronger and was based on the bonds of common language and culture. National consciousness was promoted by the advance of literature in the national language, especially in Bohemia, and considerably later in Poland. Thus the nationality conflicts of the 13th-14th centuries have played a constructive part in developing the Polish and Czech national consciousness and culture. Once the feeling of being threatened, which had worried the propertied strata of these two nations, was over, the negative language patriotism based on dislike of aliens and their influence, began slowly to recede before State patriotism. The latter attracted once more the progeny of immigrants who were more strongly attached to the soil where they were born than to the language inherited from their ancestors.

Numerous proofs of a developed national consciousness found in the source material of the 13th, and even more in the 14th century, often mislead people to identify it with modern national consciousness. However, national consciousness in the past extended - as stated above - to limited groups of society, primarily to the clergy, knights and townspeople - leaving aside the masses of peasants. This does not mean that the peasants were completely passive bystanders during the period of nationality conflicts. But whenever they did take an active part, they did so for other motives - either a keen sense of being hurt directly by the alien invaders, or class hatred against the exploiters who were sometimes foreign born, or else religious reasons. The dislike of aliens, which peasants felt, too, played only a secondary role in their behaviour and gained in importance only when combined with other motives. National solidarity which united the feudal lords and the peasants," if one can speak at all of such a thing at that period, broke down before the barriers of class and grade.

In spite of an important role played by nationality conflicts in the 13th and

31 F. G ra u s, Die Bildung..., p. 27, quotes Dalimil relation about Prince Udalryk's love for Božena, a peasant girl, as an example how chroniclers placed national divisions before class divisions; he stresses, however, the exceptional character of this text. It should be added that Dalimil interprets here only the older story by Kos ma s, I c. 36. 
14th centuries in moulding the national individuality of Poles and Czechs, it should be remembered that they did not fill the entire social life of that period. Besides the conflicts there was, even in times of special tension, the coexistence of Germans, Czechs and Poles of different grades, there was the everyday cooperation, exchange of experiences, mutual acceptance of one another's customs and culture. This particularly fruitful cultural aspect of "the German-Slavic community of destiny" deserves the special attention of historians who have, perhaps, devoted themselves too to investigating nationality conflicts.

(Translated by I. Ralf-Sues) 